\title{
Historico-geographical approach in the study of urban form: roots, development and reflections in the study of Mersin, Turkey
}

\author{
Tolga Ünlü* (]
}

\begin{abstract}
This study focuses on the emergence and development of historico-geographical approach that is systematized by M.R.G. Conzen in the mid-twentieth century through his studies of English cities. The background of historico-geographical approach was discussed in a detailed way. And the ideas of M.R.G. Conzen was examined in many early and recent studies. This study aims to identify the philosophical background of historico-geographical approach throughout its historical development and seeks to answer whether it would be appropriate to adopt the basic concepts and principles of investigation to the Turkish cities, with a focus on the city of Mersin. The research on the urban form of Mersin was uncovered before in elsewhere, but they were concentrated on the specific concepts and processes of historico-geographical approach. This study aims to reveal the comprehensive framework to investigate a city from a Conzenian view. The study on Mersin revealed that the urban growth pattern of the city brought about amalgamation of inner and middle fringe belts, and occurrence of an 'umbrella fringe belt', while dialectical interaction of morphological agents resulted in emergence of morphogenetic types in the interplay of building and plot patterns.
\end{abstract}

Keywords: Urban morphology, historico-geographical approach, Turkey, Mersin

\section{Introduction}

The character of any settlement is stimulated by the interplay of basic components of urban form - plots, buildings and streets (Conzen, 1969 [1960]; Whitehand, 2001; Barke, 2015; Oliveira, 2016; Kropf, 2017). The resulting palimpsest is a manifestation of the accumulation of forms in the course of historical development (Conzen, 2004a). Urban morphology deals with the change in urban form in this development, and may be defined as "the study of urban form" in its broadest meaning (Larkham and Jones, 1991; Larkham, 2002). It is the study of human settlements, their structure, and the process of their formation and transformation (Kropf, 2017). A further, more comprehensive definition of urban morphology is developed by Whitehand (2001), where he highlights the cycles in urban growth, the internal processes of change in different parts of the city, 
the roles of agents that give effect to the changes in urban form, and the management of urban landscape.

Moudon (1997) emphasized three distinct schools/approaches in urban morphology - Italian, British and French. Saverio Muratori and Gianfranco Caniggia in Italy, and M.R.G. Conzen in Britain were leading essentially separate lines of urban morphological research. The variations in the Italian approach have become known as the Caniggian School (Cataldi, 2003), 'Muratorian tradition' (Moudon, 1997), or the 'process typological approach' (Kropf, 2009; Oliveira, 2016). The British line of development became widely known as the Conzenian school (Moudon, 1997; Whitehand, 2001) or the historico-geographical approach (Kropf, 2009; Oliveira, 2016).

This present study focuses on the emergence and development of the historico-geographical approach that was systematized by M.R.G. Conzen in the mid-twentieth century through his studies of English cities (Conzen, 1962, 1966, 1969; Whitehand, 1981; Whitehand and Larkham, 1992; Whitehand, 2001). The background of the historico-geographical approach was discussed in detail by Whitehand (1981). And the ideas of M.R.G. Conzen have been examined in many early papers (Whitehand and Larkham, 1992; Whitehand, 2001) and recent studies (Kropf, 2017; Kristjánsdóttir, 2019; Oliveira, 2019). The present study aims to identify the philosophical background of the historico-geographical approach and considers whether it would be appropriate to adopt its basic concepts and principles of investigation in Turkish cities, with a focus on the city of Mersin. Its growth from scratch to a metropolitan region during the last two centuries makes Mersin a compelling city for morphological investigations. Research on the urban form of Mersin has been explored elsewhere (Ünlü, 2013 and 2019; Ünlü and Baş, 2016, 2017 and 2019), concentrating on specific concepts and processes of the historico-geographical approach. The present study considers the Conzenian approach.

This discussion of the evolution of urban morphology and the basic ideas and principles in the study of urban form is in three main parts. The first deals with the emergence of urban morphology in the last decades of the nineteenth century, in particular in the works of Fritz (1894) and Schlüter (1899), when the dynamic relationship between society and the urban landscape as a man-made object was recognized. The second part focuses on the resurgence of urban morphology in the 1960s, when M.R.G. Conzen introduced a more elaborate framework of the historico-geographical approach in his studies on British towns. After a short discussion of the principles, methods and concepts of the historico-geographical approach, its application to the study of change in urban form in the city of Mersin, Turkey is explored.

\section{Roots of Urban Morphology}

Kropf (2017) dates the use of 'morphology' back to the early nineteenth century, when Goethe, the famous German poet and writer, was interested in the growth and metamorphosis of animals and plants. According to Goethe, nature is not separate and self-contained, and separation of the idea and experience is unacceptable to him (Steiner, 1985). From this point of view, Goethe (1952) conceives that natural objects are diverse and in interlocking relationships. He sees everything in a ceaseless flux. He points out that knowledge is acquired through the analysis of parts. However, the parts are not isolated from each other; rather they contribute in relation to one another: "Each living creature is a complex, not a unit; even when it appears to be an individual, it nevertheless remains as an aggregation of living and independent parts, identical in idea and disposition, but in outward appearance identical or similar, unlike or dissimilar. These organisms are partly united by origin; partly they discover each other and unite" (Goethe, 1952, p.24). Accordingly, Goethe defines 'morphology' as the study of forms that considers relationships between character and function.

The thinkers of the period when Goethe developed his ideas were basically still influenced by the Aristotelean ideas on the conception of nature, which examine phenomena in interrelation to each other. However, this was basically a mechanistic relationship based on the synchronic analysis 
of the parts. Goethe did not view morphology as a science considering first the external forms of objects, but one that considered the structure of organisms at all levels of organization. Thus, while he conceived the synchronic togetherness of parts within the whole, he also explained the changes in parts and their effect on the whole in a diachronic way. That is to say, Goethe was one of those who went beyond the Aristotelean dialectics that refer to a static and fixed nature. He searched for a dynamic relationship that dealt with nature in a continuous change within a part-to-whole relationship of things.

While the scientific developments of the nineteenth century opened new doors to explain nature, social sciences were also affected by these improvements, especially the idea of interconnectedness of objects in nature to make the whole. The works of Fritz (1894) and Schlüter (1899) were the pioneering studies to place the city as a man-made phenomenon in its sociocultural context (Whitehand and Larkham 1992; Larkham 2019). Fritz, a high school history teacher in Strasbourg, classified German towns according to their layouts. He searched for the morphological elements that make towns different from villages (Simms, 2016). As Whitehand (1981) points out, Schlüter defined 'cultural landscape' (Kulturlandschaft) as the object of research in 'cultural geography' (Kulturgeographie). He sought to develop an explanatory view of the changing nature of cities, rather than a descriptive morphography. His aim was to foster "the detailed description of the visible and tangible man-made forms on the ground and their genetic and functional explanation in terms of the aims and actions of man in the course of history and in the context of nature" (Whitehand 1981, p.2). He highlighted the interdependence and interrelationship of three aspects of 'urban landscape' (Stadtlandschaft), the physical forms and appearance of a city-form, function and development (history).

The works of Geisler (1924) and Bobek (1927) were the second-generation contribution to the study of urban form, where the former developed a comprehensive classification of sites, town plans, and building types of German towns, while the latter redefined the role of the city as a living organism within the economic system of the region. Thus Bobek was expanding the content of urban morphology and placed the city and its essential aspects - form, function and change through time - in its economic, cultural and political relationships (Whitehand, 1981). However, Schlüter's main ideas were acknowledged and paved the way for the progress of urban morphology in the first half of twentieth century: the urban landscape is a context-based phenomenon, produced, formed and transformed by the continuous interventions of human beings in its specific cultural landscape.

\section{Development of Historico-geographical Approach}

M.R.G. Conzen was a key person in the development of urban morphology through his studies on British towns (1962, 1966, 1969 [1960], 1975, 1985). Following Conzen, Whitehand paved the way to diffuse urban morphology to a larger number of researchers. The Urban Morphological Research Group (UMRG), he founded at the University of Birmingham, has been acting as a centre for the historico-geographical approach in urban morphology for almost half a century since its establishment in 1974 (Oliveira, 2019). Conzen's study of Alnwick (1969) is the seminal book identifying the principles and scope of the historico-geographical approach. It was furthered by Whitehand $(1987,1991)$. Associated with the resurgence of urban morphology in the mid-twentieth century, the foundation of the International Seminar on Urban Form (ISUF) in the mid-1990s was followed by five important studies of international cooperation. The first was a collection of papers edited by Slater (1990), in which main themes developed by M.R.G. Conzen, were considered. The content and structure of another contribution (Whitehand and Larkham, 1992) followed the basic topics of the historico-geographical approach. Another study, edited by M.P. Conzen (2004), was a collection of M.R.G. Conzen's studies that were mostly not published previously. Recently, two more studies (Larkham and Conzen, 2014; Oliveira, 2019b) have been published as tributes to Whitehand's contribution to the international study of urban form. 
M.R.G. Conzen began his training in the Geographical Institute in the University of Berlin in 1926. His interest was encouraged by Schlüter's approach to cultural geography (Whitehand, 1981). After an interruption in his career due to political developments in Germany and his migration to Britain in 1933, M.R.G. Conzen was later critical of urban studies dominated by the use of quantitative models and the destructive attitude of modern urban planning in the resurgence of urban morphology after the 2nd World War. He developed the historico-geographical approach to connect functional and morphological approaches, where the former focuses on the identification of the urban community as a socio-geographical group with its socio-economic structure and function in terms of their spatial implications, while the latter identifies the formative processes and their results in the urban built environment (Conzen, 2004a). The emphasis is upon establishment of a framework of underlying relationships. It questions the nature of relationships and the ways they come together to create the urban landscape (Whitehand, 1977).

In combining functional and morphological approaches, M.R.G. Conzen (1969) further developed town-plan analysis as a method to scrutinize the changes in the urban landscape in terms of its systematic element complexes - town plan, building fabric, and land and building utilization. Town plan is the topographical arrangement of the urban built environment and contains three distinct complexes of plan elements. The first is the streets and their arrangement in a street system; the second is the plots and their aggregation in blocks; and the third is the block-plan of buildings, or their footprints. Building fabric is the three-dimensional composition and arrangement of buildings in an urban area. It is a constituent of three element of building type, materials and style. Land and building utilization is the functional purpose served by the land and buildings. Within the hierarchical nesting of three systematic form complexes, town plan provides the morphological frame that contains building fabric and land-use pattern, and the building fabric is the morphological frame for land utilization.

Urban morphological research is conducive to analysis of the cyclical nature of urban growth, the internal processes of adaptation and redevelopment, and the roles of various agents in the production of urban forms. It provides ideas for future developments and their management (Whitehand, 2001). 'Through the detailed study of urban form, both of the present and the past, we learn both what we should not do and how we can do things better' (Barke, 2018, p.11).

\subsection{Formative Processes, Outward Growth and Fringe Belts}

Outward growth is the accretionary expansion of a city leading to creation of the surrounding built-up area. M.R.G. Conzen recognized in this growth urban fringe belts, following the concept of Stadtrandzone formulated by Louis (1936) in Berlin. Conzen (1969) used fringe belts as morphological units that explicate the urban structure of a city during outward growth. He identified three distinct fringe belts - inner, middle and outer. He defined an urban fringe belt as "a belt-like zone originating from the temporarily stationary or slowly advancing fringe of a town and composed of a characteristic mixture of land use units initially seeking peripheral location" (Conzen, 1969, p.58). They are less easily recognized heterogenous areas within the internal structure of urban areas, compared to more homogeneous areas such as residential districts and central business districts. Their unity is derived from the morphological elements that had their original location near the fringe of the built-up area (Whitehand, 1967, p.223). Fringe belts of American cities are less identifiable than those of European cities due to their fewer hindrances to urban development (M. P. Conzen, 2009).

According to Whitehand (1987, p. 76), the fringe-belt concept is "arguably the most important single contribution to urban morphology to arise out of the morphogenetic tradition". He expanded the scope of fringe-belt studies to the regional scale (Whitehand 1967), developing the economic rationale behind the emergence of fringe-belts in relation to development cycles of housing, and 
"battled" (Barke, 2019) for elaboration of fringe-belt studies in different cultural contexts1. He developed an innovation/building cycle model after Conzen's fringe-belt model, presenting the interrelation between fringe-belt formation and modification processes in relation to bid-rent theory, building activities and innovation (Figure 1). Furthermore, while fringe-belt studies developed in different branches (Ünlü, 2013), Whitehand was leading the way by establishing frameworks for exploration of fringe belts in relation to decision-making processes of developers and planning authorities, their recognition in the planning process and demonstration of their ecological importance in urban form (Barke, 2019).

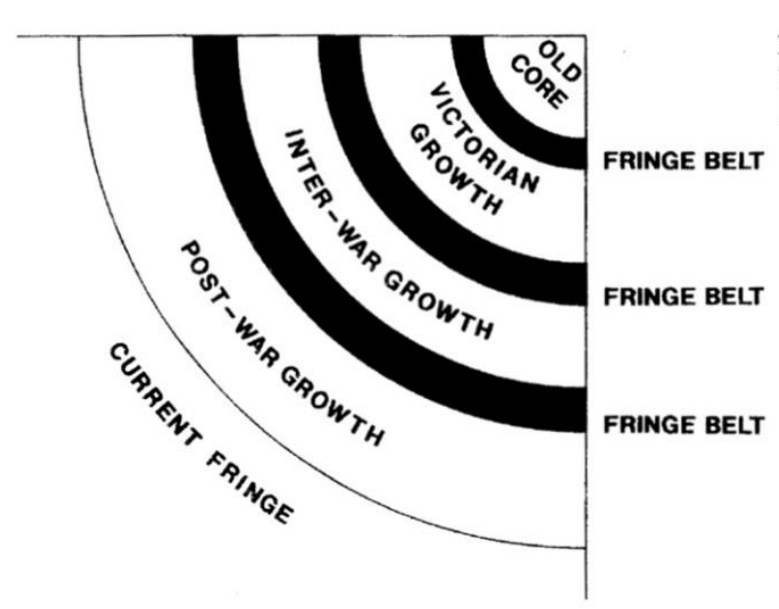

fringe-belt model

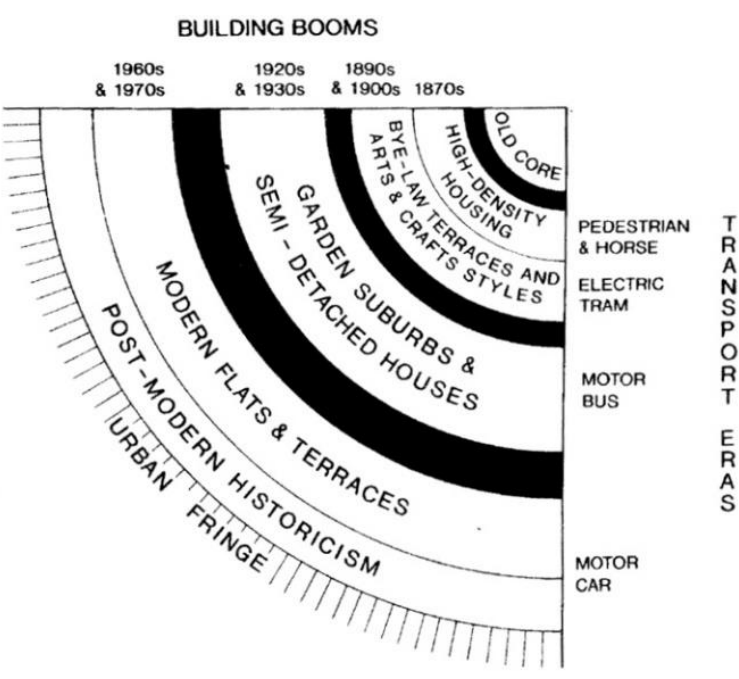

innovation/building-cycle model

Figure 1 Conzen's fringe-belt model and Whitehand's innovation/building cycle model

\subsection{Transformative Processes and Internal Change}

While the city expands through the additive processes of outward growth, the built-up area experiences the transformative processes of internal change (Whitehand, 2001). Conzen (2004b) portrays four main processes of internal change. Building repletion occurs through filling up the plots with new buildings. Building replacement comes into being through the destruction of older buildings and construction of new ones due to changing functional requirements. It proceeds in a piecemeal fashion, separately on individual plots. Usually associated with the replacement process, plot pattern metamorphosis appears through amalgamation, division and truncation of plots. In this way, the plot pattern is adapted to newly emerging building types. Central commercial redevelopment is the last process that occurs in a larger context and produces new block patterns and street systems, thanks to its comprehensive and augmentative nature.

Among others, building repletion and replacement processes lead to emergence of the burgage cycle in plots. This is the gradual filling up of plots with new buildings through a succession of institutive, repletive, climax, and recessive phases, defined by the changes in building coverage. The burgage cycle comes to an end with demolition of buildings and creation of urban fallow. This is followed by preparation of the plot for new development (Figure 2).

\footnotetext{
${ }^{1}$ The author became acquainted with the field of urban morphology, and especially with fringe-belt studies, during his visit to the UMRG at the University of Birmingham in 2012, and is indebted to J.W.R. Whitehand for being the main influence and source of inspiration for his urban morphological research.
} 


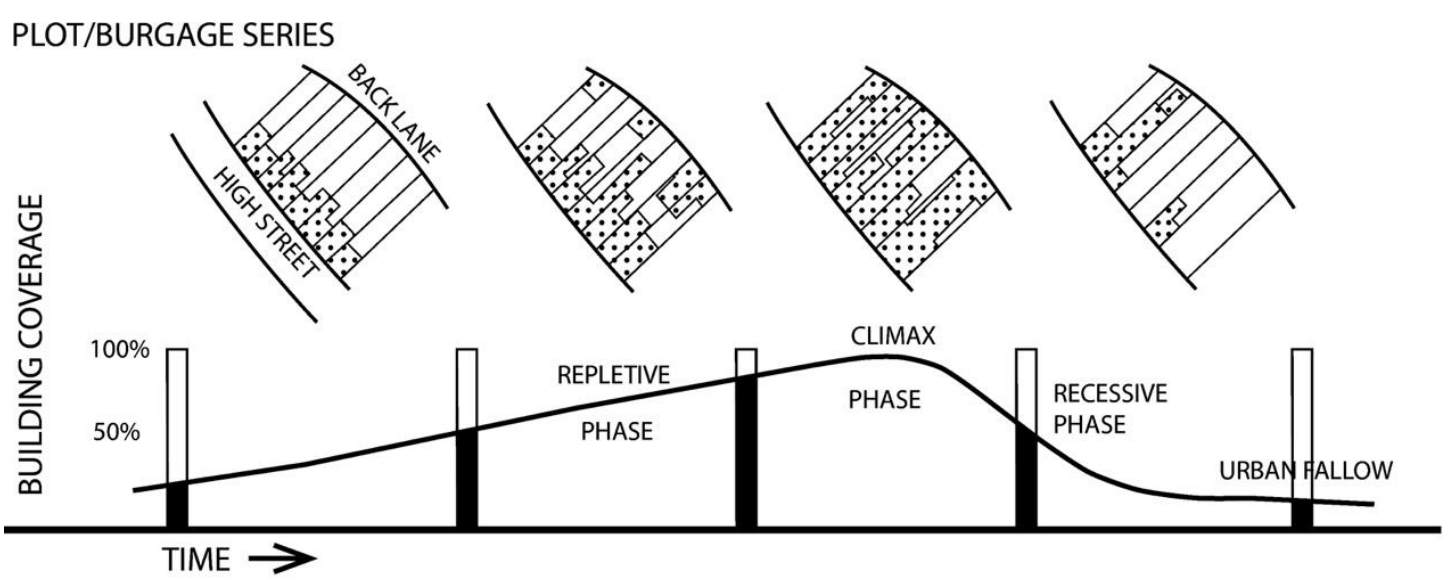

Page | 6

Figure 2 Burgage cycle (after Larkham and Jones 1991, p.69)

Internal change may result in morphological heterogeneity in the urban built environment. This gives historicity to the city as a result of accumulation of forms throughout its historical and cultural development. The degree of historicity may vary according to the intensity of different forms in different periods, their spatial arrangement and integration. As successive periods leave their forms in the built environment, the city becomes a palimpsest, a record that is subject to morphological analysis of systematic form complexes, where town plan is the most resistant to the changing requirements of society. Land utilization is the most subject to changing circumstances.

The morphological processes within the interplay of systematic form complexes that are affected by the different aims, aspirations and motivations of morphological agents result in the emergence of morphological regions as the areas of morphological unity or homogeneity in different parts of a city in their combination of streets, plots and buildings. The entire city is a phenomenon of a hierarchical nesting of morphological regions, in which morphotopes act as the smallest regions determined by the grouping of the building fabric of a distinctive period. It is followed by neighbourhood units, town quarters, and major regions (Conzen, 1988).

Although Conzen $(1975,1988)$ revealed historically stratified morphological regions within a hierarchy (Figure 3), his emphasis is not on separate entities, rather the focus is upon how those entities come together to make the whole (Ku, 2019). The study of morphological regions houses possibilities to develop cross-cultural comparisons in different contexts and has great potential to link research to practice in developing planning decisions, although it is not used sufficiently in this way (Whitehand, 2009). 


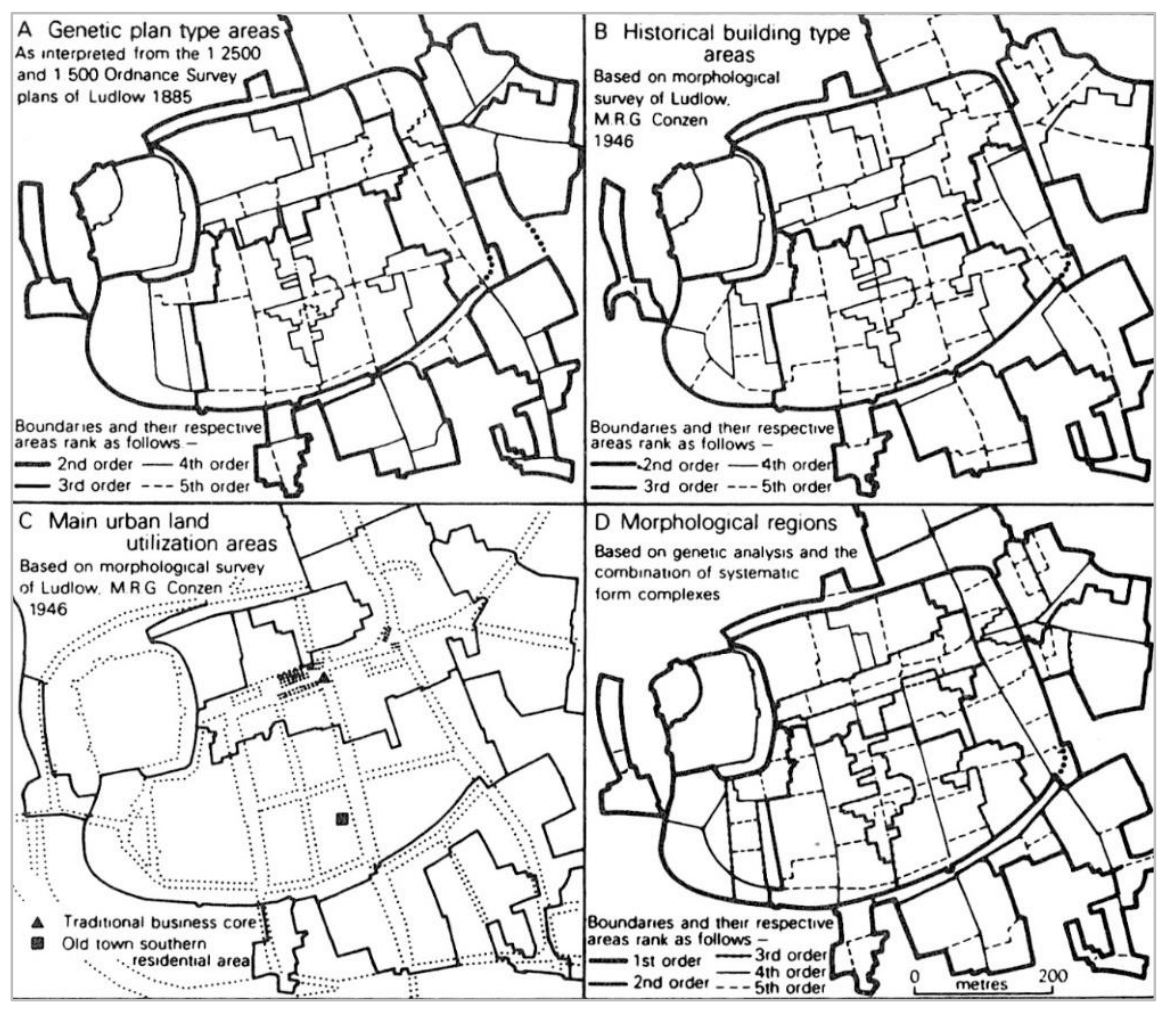

Figure 3 Morphological regions in Ludlow (Conzen, 1988)

\subsection{Agents of Change}

Larkham (2019) highlights that Whitehand (1977) moved morphologists away from their heavy reliance on the urban landscape as a source of evidence, and suggested a framework of inference based on innovation and construction activity within the context of social and economic forces. In this way, the study of urban form entered a new path, in which the decision-making processes and the role of agency were given greater scrutiny. He defined the property owners, developers, builders, and architects as 'the makers of the urban landscape' (Whitehand, 1991). After detailed studies on development control through planning applications (Whitehand and Whitehand, 1983, 1984), Whitehand (1992) highlighted the factors that influenced the decisions and actions of morphological agents in the shaping of urban form. Important were the life-cycles of fashions, the dependence of developers on economic factors, the conflict between conservation and development, the need for ingenuity in infill and piecemeal redevelopments, and poorly coordinated activities.

In the same period, Larkham (1988) recognized two groups of agents. First were the direct agents as the initiators of a proposal: the architects, site owners, consultants, builders and suppliers. They were closely integrated with each other in order to realize the proposal of the initiator. The indirect agents include local amenity groups, the public, and local planning officers, whose influence on taking decisions are very limited.

The complex web of relationships between morphological agents requires investigation in a multidisciplinary way, since their motivations, expectations and decisions could change due to changing economic and social conditions of society. Larkham (2019, p. 84) points out that "Politics and economics have great parts to play in explaining so many decision-making processes at all scales" 


\subsection{Management of the Urban Landscape}

Drawing attention to the loss of human scale and the 'facelessness' of architecture, Conzen (1975) criticized the dominant planning approach of the period. He highlighted the importance of the urban built environment as a source of intellectual value. The historical development of urban form provides a sense of continuity and diversity of human efforts and achievement at different periods, and helps people to be rooted in an area through comprehension of its character as a result of accumulation of forms. It is also conducive to professionals to develop proposals to intervene in the urban space and to manage urban change. It provides a rational basis for successful management of the urban landscape.

Conzenian ideas conceive the built environment as a source of accumulated wisdom, and a basis to develop ways to manage change (Whitehand, 1992). Along this path, provision of sound bases for practitioners to understand and comprehend the context is one of the main challenges of urban morphology (Whitehand, 2009). The proper management of the urban landscape has direct effect on the quality of the built environment, which should not be limited to economic concerns. It has significant influence on the culture of the society. This requires developing bridges between morphological research and practice (architecture, planning etc.).

Practitioners are focused on "what should be done" or "what will work" within a normative viewpoint, but give little attention to "what the city is made of" (Moudon 1992). However, morphological research has the potential to provide the means to understand the basic relationships within the processes of formation and transformation of the built environment and to develop a basic background and framework for urbanism (Kropf, 2006, p.73). Research on urban morphology can provide practitioners with opportunities to develop holistic views of the shaping of urban form that can lead to the development of guidance of the desired urban pattern (Hall 2013).

Making the connection between urban morphological research and practice requires the development of a responsive planning policy. The development of a historico-geographical approach provides opportunities to make this connection strongly on the basis of utilizing the concepts of the fringe belt and the morphological region in developing planning decisions.

To summarize, the historico-geographical approach to urban form is basically founded on three principles. First, the urban landscape is formed and transformed through a continuous complex web of interactions of systematic form complexes. Secondly, these form complexes and the morphogenetic regions act within hierarchical nesting, from the smallest cells in the urban landscape to the entire city. Thirdly, urban form is subject to continuous adaptation, transformation and replacement processes through the continuous interventions of diverse agents within its historical development. As new forms are added to the existing ones in urban development, the built environment becomes the objectivation of the human spirit, or genius loci, of that society (Conzen, 1975). It is the "transformation of mind into matter in the form of a great, composite artefact on the earth's surface, wrought with the materials of nature" (Conzen 2004b, p.40).

\section{Reflections on the Study of Mersin, Turkey}

The morphological research on Turkish cities has been growing in the last two decades, and has accelerated after the foundation of the Turkish Network of Urban Morphology in 2014. Among them, fringe-belt studies are getting more attention (Ünlü, 2013; Kubat and Gümrü, 2014; Hazar and Kubat, 2015; Ünlü and Baş, 2016; Kubat, 2019; Ünlü and Baş, 2019; Hazar and Özkan, 2020).

The sound framework that the historico-geographical approach provides for investigation of the changes in urban form is utilized in examination of urban growth and internal changes in the city of Mersin, Turkey. Located along the Mediterranean coast of Turkey, Mersin began to emerge at the beginning of the nineteenth century, and in almost two centuries it evolved into a metropolitan city 
from a coastal village comprising 'a few huts on the shore' (Beaufort, 1818). Its transformation into a prominent port city in the region has been subject to a series of studies (Selvi Ünlü, 2009; Selvi Ünlü and Göksu, 2018; Selvi Ünlü and Kayam, 2019; Selvi Ünlü and Ünlü, 2009, 2012; Yenişehirlioğlu, 2010; Yenişehirlioğlu et.al., 2019) and morphological research (Ünlü, 2013 and 2019; Ünlü and Baş, 2016, 2017 and 2019).

\subsection{Outward Growth and Fringe Belts}

The city centre of Mersin had been structured during its development from the nineteenth until the mid-twentieth century. Beginning with the second half of the twentieth century, the city experienced a rapid outward growth through the addition of new residential areas - formal and informal (Figure 4). In this urban growth, three fringe belts - IFB, MFB and OFB - became recognizable since new housing developments leapfrogged and enveloped them (Figure 5).

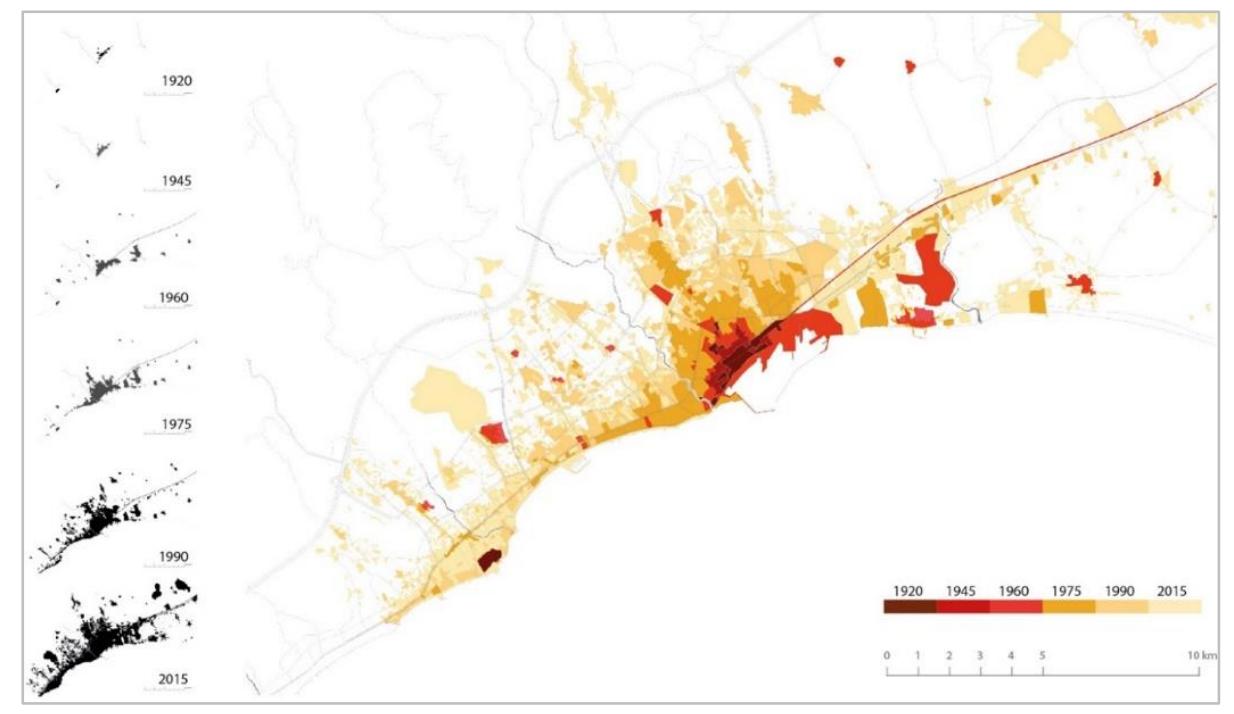

Figure 4 The built-up area of Mersin between 1920 and 2015.

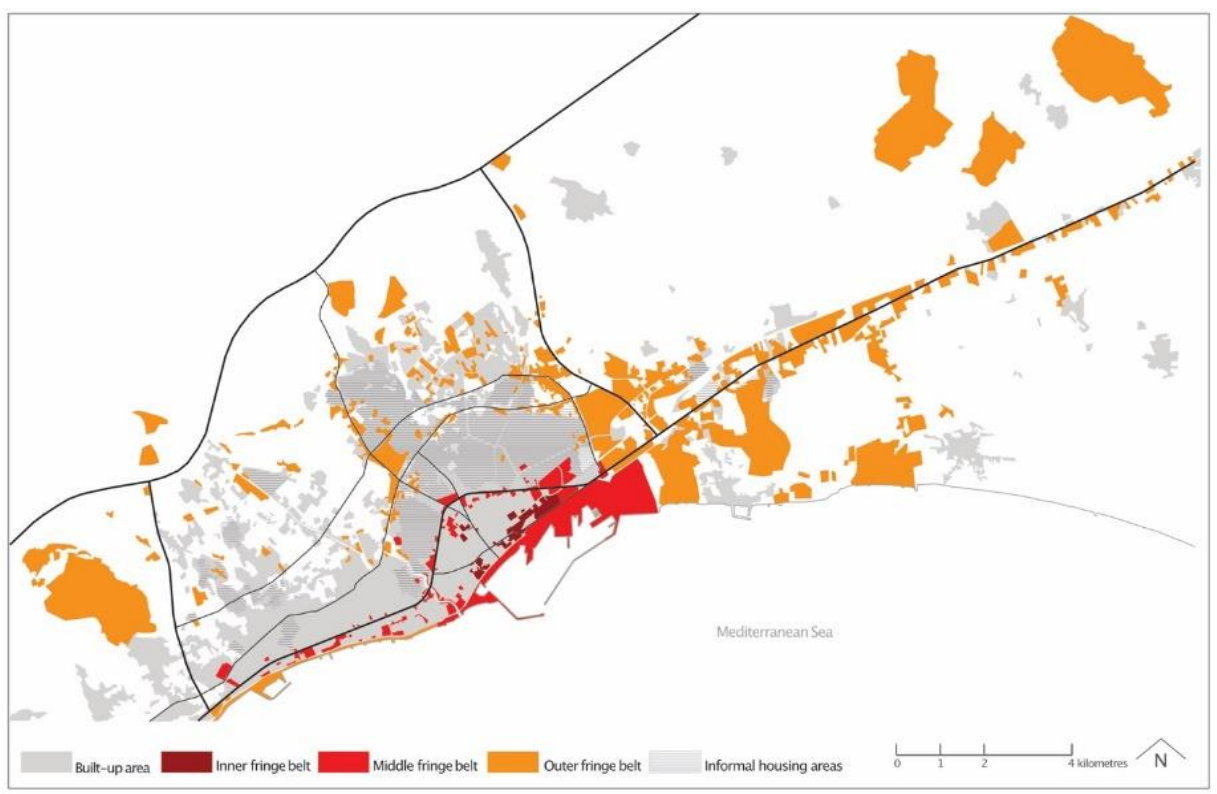

Figure 5 Fringe belts of Mersin

The development of the IFB and its relationship to the MFB revealed characteristics peculiar to Mersin. Due of the lack of a city wall surrounding the centre, reflecting its foundation in the nineteenth century, Mersin did not experience a continuous inner fringe belt such as would be expected from a medieval city. Thus, the IFB developed in three separate sections - west, east and 
north - each of which had its own character. Another reason for the disconnectedness of the IFB was the occurrence of late industrialization. Mersin became the port city of the region during its rapid development throughout the nineteenth century, playing the role of transfer point with its hinterland, where the raw materials were acquired from the fertile agricultural lands and the industrialized countries. Thus, from the beginning the existence of the city was dependent on international commercial relationships.

The advent of a railway station and development of industrial uses and warehouses around it triggered fringe-belt formation in the eastern section, while institutional uses such as a cultural centre, schools and open spaces such as public parks dominated the western section. The northern section was occupied by industrial uses, basically by the first examples of cotton factories of the period. The character of each section remained the same until the mid-twentieth century. Since then, migration of factories to the surrounding region resulted in the transformation of industrial uses in the eastern and northern sections into institutional uses. As a result of fringe-belt alienation processes, the transformation of factories into residential uses and commercial complexes is evident in these sections. The western section was the earliest one to face consolidation due to the emergence of new neighbourhoods beyond. Çamlıbel District is the most prominent one among those residential accretions. It was the first housing environment within the outward growth of the city and presented a new urban environment in the city, composed of single-family detached houses in large gardens. The consolidation of other sections followed the western section after the emergence of leapfrog developments of residential accretions.

As the middle fringe belt was in formation phase in the mid-twentieth century, when the sections of the IFB were mostly consolidated, the ring road that was constructed in the late 1950s acted as a fixation line to the MFB and attracted campus developments of institutional uses. The addition of a number of open spaces, such as public parks and large-scale sports areas, military quarters, and a transportation centre of a bus terminal gave the MFB its continuity in urban form along the ring road. However, a more interesting finding is the merging of the IFB and MFB. New fringe-belt uses resulted in the expansion of the northern and eastern sections, and also connected two fringe belts. The IFB had lost its character as a separate morphological unit. The merging of two fringe belts was also facilitated by the construction of a modern port area to the east of the city. This was stretched out along the waterfront and joined the eastern and western sections of the IFB and the MFB to each other.

The MFB was consolidated during the three decades after its formation. Informal housing settlements were in remarkably close vicinity to the MFB. They had been a prominent feature of housing provision in Turkish cities during the second half of the twentieth century. They emerged as a form of self-built housing on the peripheral lands of the city, where newcomers from the agricultural regions migrated to find new jobs and saw the possibility of land on which to build houses. The immigrants came to cities as a result of the modernization policies of the central government. Since they lost their jobs in the agricultural lands, Turkish cities were faced with their rapid arrival to the outskirts, where informal settlements occurred as a reaction to housing shortages. A consequence of this process was the considerable number of informal housing settlements between the MFB and the OFB in Mersin (Figure 5).

The sites of the outer fringe belt had been located in a more scattered way in the peripheral lands of the city. The university campus, new large-scale sports areas that were built for the Mediterranean Games in 2013, institutional campuses that were located in the peripheral lands as a result of central government decisions, large-scale transportation hubs, and organized industrial campuses were the components of the OFB in its formation phase. However, one of the most distinctive revelations in Mersin was the emergence of an 'umbrella fringe belt'. This covers and envelopes the previous fringe belts and sub centres and other small-scale settlements along the 
regional expressway, which is the new fixation line for new fringe belt units that sort peripheral lands (Ünlü and Baş, 2016) (Figure 6).

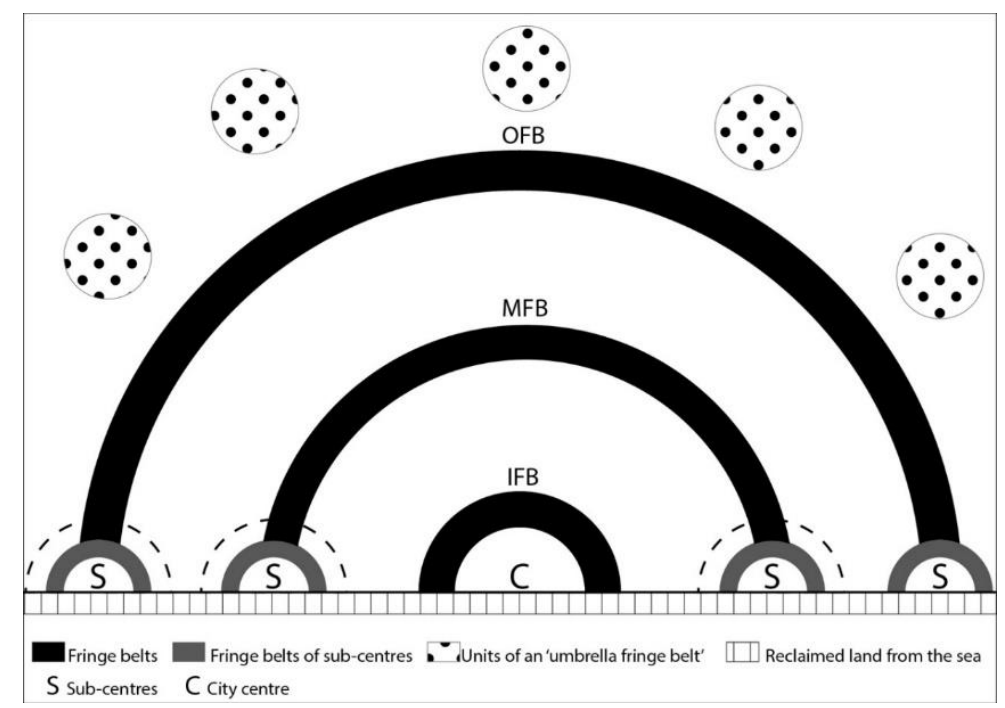

Figure 6 The umbrella fringe-belt model for the development of cities at the metropolitan scale.

\subsection{Internal Change, Morphological Processes and Agents of Change}

As cities grow outward in an additive process, the built-up areas reflect formative processes of townscape - accumulation, adaptation, transformation and replacement (Conzen, 1966, p.57-59). Çamlıbel residential settlement is a second order residential integument that leapfrogged the western section of the IFB and was shaped as the living environment for a newly emerging bourgeoisie. It is expected to follow more morphological processes in this area than in other new developments. The documents in the Ottoman archives reveal that the settlement was initiated in the then agricultural lands by a landowner, named Nakkaş, in the first decade of twentieth century. Since then, Çamlıbel is faced with complex morphological processes, which are evident in emergent morphogenetic types within the interplay of changing plot pattern, building types and land utilization (Ünlü and Baş, 2017).

The first period of development in Çamlıbel is the institutive phase that experienced the primary accumulation of forms through insertion of new plots as a result of the subdivision process, and construction of two-storey single-family detached houses as the dominant building type of the period. Notable tradesmen built their houses in the first decades of the twentieth century. In this period, that continued until the 1960s, the average rate of plot coverage, building density and building height were $0.33,0.50$ and 2 respectively. Çamlıbel District was faced with the emergence of apartment blocks as the dominant building type in the second period until the 1990s, when the population of Mersin had tripled from 48000 people in 1950 to 152000 people in 1980 . As a response to the growing need for new homes for the rapidly growing population, the Law of Flat Ownership, enacted in 1965, facilitated construction of apartment blocks, not only in Mersin but also in all cities countrywide. It enabled ownership of a single plot by numerous people. Thus the replacement process resulted in destruction of single-family houses and construction of apartment blocks very quickly in the second period. However, the replacement process did not come to an end since $29 \%$ of all buildings constructed were still single-family houses in this period. Since the replacement process came into being in the plot heads within the parent plot, the plot tails were cut off from the parent plot in order to erect new apartment blocks through a secondary accumulation process. The consequence of morphological processes in the second period was an increase in the average value of plot coverage, building density and building height: $0.57,1.78$ and 2.45 respectively. The redevelopment cycle within plots resulted in a sharp increase in the average value of plot coverage, building density and building height, $0.80,3.60,4.50$ respectively, in the third phase, when Çamlıbel district was almost entirely composed of apartment blocks (Figure 7). 
Only $7 \%$ of single-family detached houses were kept in this period due to the fact that they are listed buildings under conservation.

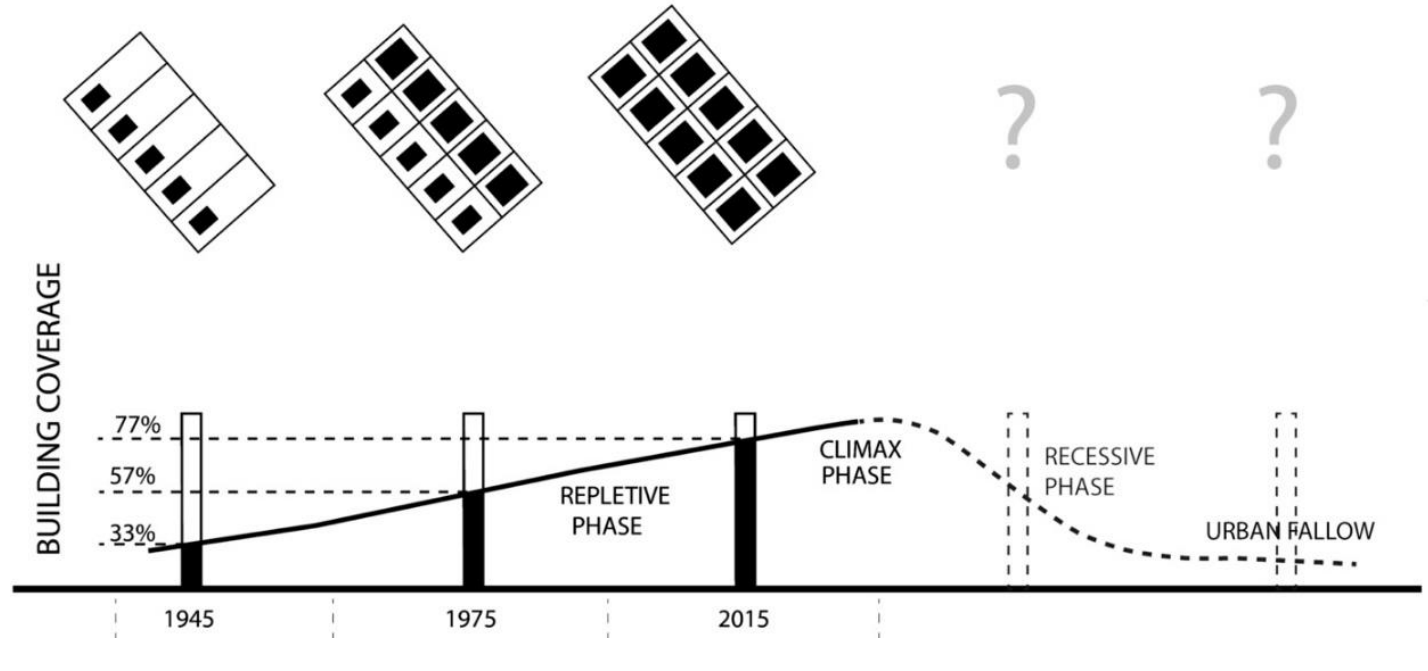

Figure 7 Redevelopment cycle in Çamlıbel

The gradual transformation of the urban landscape in Çamlıbel District came into being through accumulation and replacement processes in three phases that were accompanied by generation, degeneration and regeneration of the context (Ünlü and Baş 2017). In the first phase, a primary accumulation process generated a context composed of single-family houses in large plots. The second phase experienced degeneration of the context, since apartment blocks were erected in the plot heads through the replacement process and in the derivative plots, created in the plot tails of the parent plots, through secondary accumulation processes. At this time, single-family houses and apartment blocks existed together. When the residential area was recreated almost totally with apartment blocks, the regeneration of the context has no or very little connection with the first phase of redevelopment. Thus, the prevailing morphological process in the historico-geographical development of Çamlıbel is replacement that is also initiated by planning decisions and related laws, and morphological agents. All agents (landowners, contractors, planning authorities, builders) taking part in the replacement process aimed at raising their profits through increasing development rights. Thus, small-scale alliances of morphological agents take place within the boundaries of a plot with the motivation of profit maximization: landowners look to build as many units as possible and small-scale contractors requesting more construction rights to maximize, while local authorities seek to facilitate the construction processes.

\section{Conclusion}

Commencing with an investigation into the roots of urban morphology, this study aimed at developing a discussion on the principles, concepts and methods of the historico-geographical approach to urban form. The roots lie in Goethe's studies on the metamorphosis of plants and animals. What he brought about as a philosophical basis for morphological research was that nature is conceived as a process of continuous change in its historical development. That is to say, he transcended the synchronic dialectics of Aristoteles and integrated it with a diachronic one. This integration was later developed by Hegel and systematized by Engels and Marx through setting the dialectical materialism in the nineteenth century as a philosophical and scientific approach to explain the processes of change as products and reflections of material conditions. According to Schlüter, these conditions are embedded within the cultural landscape, in which he defined 'urban landscape' in the interrelationships of form, function and development. In a similar fashion, M.R.G. Conzen analyzed the changes to urban form in a dialectical way, and developed the historicogeographical approach to scrutinize the underlying relationships and processes. The town-plan 
analysis method questions the nature of relationships of parts in the urban landscape in order to create the whole through the hierarchical nesting and dynamic interplay of three form complexes - town plan, building fabric, and land and building utilization. In this way, he analyzed the changes to urban form synchronically and diachronically.

Along the way, formative processes lead to accretionary expansion and formation of urban fringe belts. M.R.G. Conzen used the fringe-belt concept as a constitutive morphological element of urban form to explain urban growth processes. Whitehand furthered this approach and examined the formation and modification of fringe belts in relation to the development cycles of housing. Conzen focused on internal change that is triggered by the transformative processes of building repletion, building replacement, plot pattern metamorphosis, and central commercial development. These processes are activated by morphological agents, the makers of urban landscape (Whitehand, 1992a), within a complex web of relationships in a decision-making process.

Investigation of the historico-geographical development of Mersin, from the nineteenth century to the present day, revealed that three distinct fringe belts - inner, middle and outer - are recognizable within the internal structure of the city, although the inner and middle fringe belts are amalgamated. They emphasize the cyclical nature of urban growth, within which the residential developments of new periods emerge through leapfrogging of fringe belts. Apart from three fringe belts, emergence of a new fringe belt, an 'umbrella fringe belt', at a regional scale is prominent. The umbrella fringe-belt model needs further discussion in different cultural contexts, to assess whether it could be an explanatory concept to investigate the historico-development of cities at the metropolitan scale.

The detailed plot-based study of Çamlıbel residential development drew attention to a redevelopment cycle in three phases, in which the urban environment, consisting of single-family houses in large gardens is transformed into an urban landscape of apartment blocks through accumulation and replacement processes that are facilitated by small-scale alliances in individual plots.

Although investigation of the historico-geographical development of Mersin demonstrated the basic characteristics of outward growth and internal change, further studies are required to elucidate and compare the features of morphological processes in Turkish cities.

\section{Acknowledgments}

The author is grateful to Jeremy Whitehand and Susan Whitehand for their comments and suggestions for this paper.

\section{References}

Barke. M. (2015) Further thoughts on research and practice in urban morphology: a British perspective. Urban Morphology 19(1):96-99.

Barke. M. (2018) The Importance of Urban Form as an Object of Study. In Oliveira (ed) Teaching Urban Morphology Springer, Cham, pp. 11-30.

Barke M (2019) Fringe Belts. In Oliveira (ed) JWR Whitehand and the Historico-geographical Approach to Urban Morphology Springer, Cham, pp. 47-66.

Beaufort F (1817) Karamania or a brief description of the Southeast Coasts of Asia Minor and the remains of the antiquity. Printed for R, Hunter, London

Bobek, H. (1927) Grundfragen der Stadtgeographie. Geogr. Anz. 28, 213-24.

Cataldi, G. (2003) From Muratori to Caniggia: the origins and development of the Italian school of design typology. Urban Morphology 1:96-99.

Conzen, M.P. (2004) Thinking about urban form: papers on urban morphology, M.R.G. Conzen. Peter Lang, Bern 
Conzen M.P (2009) How cities internalize their former urban fringes: a cross-cultural comparison. Urban Morphol 13(1):29-54

Conzen, M. R. G. (1958) The growth and character of Whitby. In: Daysh, G. H. J. (ed.) A survey of Whitby and the surrounding area. Shakespeare Head Press, Eton, pp. 49-89.

Conzen, M. R. G. (1960) Alnwick, Northumberland: a study in town-plan analysis. Institute of British Geographers Publication 27. George Philip, London.

Conzen, M.R.G. (1962) 'The plan analysis of an English city centre', in Norborg, K. (ed.) 'Proceedings of the I.G.U. symposium on urban geography, Lund, 1960', Lund Studies in Geography B vol. 24 pp. 383-414

Conzen, M.R.G. (1966) Historical townscapes in Britain: a problem in applied geography, in House, J.W. (ed.) Northern geographical essays in honour of G.H.J. Daysh Oriel Press, Newcastle upon Tyne. Reprinted in Whitehand, J.W.R. (ed.) (1981).

Conzen, M. R. G. (1969) Alnwick, Northumberland: a study in town-plan analysis, 2nd edn. Institute of British Geograpers Publication 27. Institute of British Geographers, London.

Conzen, M. R. G. (1975) Geography and townscape conservation. In: Uhlig, H. and Lienau, C. (eds) AngloGerman symposium in applied geography. Lenz, Giessen, pp. 95-102.

Conzen, M.R.G. (1988) 'Morphogenesis, morphological regions and secular human agency in the historic townscape, as exemplified by Ludlow', in Denecke, D. and Shaw, G. (eds) Urban historical geography Cambridge University Press, Cambridge (published in Conzen (2004))

Conzen, M. R. G. (2004a) Urban morphology: A geographical approach. In: Thinking about urban form: papers on urban morphology (Conzen, M. P., ed.). Peter Lang, Bern, pp. 47-59.

Conzen, M. R. G. (2004b) A Framework for the comparative study of townscapes, in relation to the concepts of region and environmental complex, In: Thinking about urban form: papers on urban morphology (Conzen, M. P., ed.). Peter Lang, Bern, pp. 35-44.

Fritz J (1894) Deutsche Stadtanlangen. In: Beilage zum Programm 520 edes Lyzeums Strassburg. Heitz, Strassburg.

Geisler W (1924) Die deutsche Stadt: ein Beitrag zur Morphologie der Kulturlandschaft. Engelhorn, Stuttgart

Goethe J. W. (1952) Goethe's Botanical Writings, Ox Bow Press

Hall T (2013) The potential influence of urban morphology on planning practice. Urban Morphology 17:5455

Hazar D, Kubat AS (2015) Fringe belts in the process of urban planning and design: comport,ve analysis of İstanbul and Barcelona. AZ ITU Journal of the Faculty of Architecture, 12 (1):53-65

Hazar D, Özkan SP (2020) Public and Ecological Significance of Fringe Belts: The Case of Military Areas in İzmir. Urban Academy:Journal of Urban Culture and Management 13(1): 10-21.

Kristjánsdóttir, S. (2019) Roots of urban morphology. Iconarp 7, pp. 15-36.

Kropf K. (2006) Crisis in the typological process and the language of innovation and tradition. Urban Morphology 10(1):70-73

Kropf K. (2009) Aspects of urban form. Urban Morphology 13:105-120

Kropf, K. (2017) The handbook of urban morphology. Chichester, Wiley.

Ku, K. (2019) Urban Morphological Regions: Development of an Idea. In Oliveira (ed) JWR Whitehand and the Historico-geographical Approach to Urban Morphology Springer, Cham, pp. 33-46.

Kubat AS (2019) Exploring the Fringe-Belt Phenomenon in a Multi-Nuclear City: The Case of Istanbul; Iconarp 7:95-134.

Kubat AS, Gümru F (2014) Investigating the fringe belt concept: The case of Istanbul, Turkey. International Seminer on Urban Form, Porto, Portugal, 3-6 Temmuz 2014, unpublished paper

Larkham P.J. (1988) Agents and types of change in the conserved townscape. Transactions of the Institute of British Geographers 13:148-164

Larkham, P.J. (2002) Misusng 'morphology'. Urban Morphology 6(2):95-8.

Larkham, P.J. (2006) The study of urban form in Great Britain. Urban Morphology 10(2):117-141.

Larkham, P.J. (2019) Extending urban morphology: drawing together quantitative and qualitative approaches. In: L. D'Acci (ed.) The mathematics of urban morphology. Springer, Switzerland.

Larkham P.J. and Conzen, M.P. (2014) Shapers of urban form: explorations in morphological agency. Routledge, New York

Larkham, P.J. and Jones, A. N. (1991) A glossary of urban form. Historical Geography Research Series no:26, Urban Morphology Research Group, University of Birmingham, Birmingham.

Louis, H. (1936). Die geographische Gliederung von Gross-Berlin. In: Louis, H. and Panzer, W. (eds) Landerkundliche Forschung: Festchrift zur Vollendung der sechzigsben Lebensjahrer Norbert Krebs (146171). Engelhorn, Stuttgart. 
Moudon, A. V. (1997) Urban morphology as an emerging interdisciplinary field. Urban Morphology 1(1):3-10.

Oliveira, V. (2016) Urban morphology: an introduction to the study of the physical form of cities. Springer, Dordrecht

Oliveira, V. (2019a) An historico-geographical theory of urban form. Journal of Urbanism: International Research on Placemaking and Urban Sustainability, 12(4)

Oliveira, V. (2019b) J.W.R. Whitehand and the Historico-geographical Approach to Urban Morphology, Springer, Cham.

Schlüter, O. (1899). Bemerkungen zur Siedelungs-geographie. Geographische Zeitschrift, 5, 65-84.

Selvi Ünlü T (2009) Bir Iskeleden Liman Kentine Doğu Akdeniz'in Önemli Bir Limanı Olarak On Dokuzuncu Yüzyılın İkinci Yarısında Mersin'de Mekansal Gelişim [Development of Urban Form of Mersin during the second half of nineteenth century]. Planlama 3(4):5-26

Selvi Ünlü T, Göksu E (2018) Osmanlı'dan ulus devlete Dogu Akdeniz liman kentlerinde mekana müdahale ve kent kimliğindeki değişim: Mersin ve Volos örneği [Changing urban identity in the Eastern Mediterranean port cities from the Ottoman period to the nation states: The case of Mersin and Volos].

Selvi Ünlü T., Kayam M. (2019) "The Port of Mersin from the Nineteenth Century to Twentieth Century" in Yenişehirlioğlu F., Özveren E., Selvi Ünlü T. (eds) Eastern Mediterranean Port Cities: A Study of Mersin, Turkey-From Antiquity to Modernity, Springer, Switzerland, pp. 155-177.

Selvi Ünlü T, Ünlü T (2009) Mersin from railway station to the lighthouse. Mersin Chamber of Commerce and Industry, Mersin Books Series-1, Mersin

Ünlü, T., Selvi Ünlü, T. (2012) Developing commerce, changing city: Mersin, 1850-1950, Mersin Chamber of Commerce and Industry, Mersin Books Series-1, Mersin.

Simms A. (2016) Johannes Fritz and the origins of urban morphology. Urban Morphology 20(1):62-64.

Slater, T. (1990) The built form of western cities: essays for MRG Conzen on the occasion of his eightieth birthday. Leicester University Press, Leicester

Steiner R. (1985) Goethe's world view. Mercury Press, New York.

Ünlü, T. (2013) Transformation of a Mediterranean port city into a 'city of clutter': dualities in the urban landscape - the case of Mersin. Cities 30(1):175-185.

Ünlü, T. (2019) Managing the urban change: A morphological perspective for planning. ICONARP International Journal of Architecture and Planning, 7, 55-72.

Ünlü, T. and Baş, Y. (2016) 'Multi-nuclear growth patterns in a rapidly changing Turkish city: a fringe-belt perspective', Urban Morphology 20 (2), 107-21.

Ünlü, T. and Baş, Y. (2017) Morphological processes and the making of residential forms: morphogenetic types in Turkish cities. Urban Morphology 21(2):105-122

Ünlü, T. and Baş, Y. (2019) Changes to Urban Form in Eastern Mediterranean Port Cities: Formation and Transformation of the Çamlıbel Neighborhood in Mersin. In Yenişehirlioğlu F., Özveren E., Selvi Ünlü T. (eds) Eastern Mediterranean Port Cities: A Study of Mersin, Turkey-From Antiquity to Modernity, Springer, Switzerland, pp. 221-239.

Whitehand, J.W.R. (1967) 'Fringe belts: a neglected aspect of urban geography', Transactions of the Institute of British Geographers 41.

Whitehand, J. W. R. (1977) The basis for an historico-geographical theory of urban form. Transactions of the Institute of British Geographers, New Series, Vol. 2, No. 3, pp. 400-416.

Whitehand, J. W. R. (1981) Conzenian ideas: extension and development. In: Whitehand, J. W. R. (ed.) The urban landscape: historical development and management. Papers by M. R. G. Conzen. Institute of British Geographers Special Publication 13. Academic Press, London 127-52.

Whitehand, J.W.R. (1987) The changing face of cities: a study of development cycles and urban form Institute of British Geographers Special Publication no. 21, Blackwell, Oxford

Whitehand, J.W.R. (1991) The making of the urban landscape IBG Special Publication no. 26, Blackwell, Oxford Whitehand J.W.R. (1992) Makers of the Residential Landscape: Conflict and Change in Outer London. Transactions of the Institute of British Geographers 15:87-101.

Whitehand, J. W. R. (2001) British urban morphology: the Conzenian tradition. Urban Morphology, 5(2), 103109.

Whitehand, J. W. R. (2009) The structure of urban landscapes: strengthening research and practice. Urban Morphology 13(1):5-27.

Whitehand, J. W. R. (2012) Issues in urban morphology. Urban Morphology 16(1):55-65.

Whitehand, J. W. R. (2019) ISUF and Urban Morphology: 25 years on and counting. Urban Morphology 23(2):103-4. 
Whitehand, J. W. R. and Larkham, P. J. (1992) The urban landscape: issues and perspectives. In: Whitehand, J. W. R. and Larkham, P. J. (eds) Urban landscapes: International perspectives (Routledge, London)1-19.

Whitehand, J.W.R. and Whitehand, S.M. (1983) 'The study of physical change in town centres: research procedures and types of change', Transactions of the Institute of British Geographers 8:483-507

Whitehand JWR, Whitehand SM (1984) The physical fabric of town centres: the agents of change. Transactions of the Institute of British Geographers 9:231-247

Yenişehirlioğlu F (2010) Urban textures and architectural styles after the Tanzimat. In: Baruh LT, Kechriotis V (eds) Economy and society on both shores of the Aegean. Alpha Bank Historical Archives, Athens, pp 487526

Yenişehirlioğlu F., Özveren E., Selvi Ünlü (2019) Eastern Mediterranean Port Cities: A Study of Mersin, Turkey-From Antiquity to Modernity, Springer, Switzerland.

\section{Resume}

Tolga Ünlü took his bachelor, graduate and PhD degrees at the Department of City and Regional Planning, Middle East Technical University. His research is focused on urban morphology, urban design and planning practice with a particular attention on urban growth and development of fringe belts, and on the relationship between research and practice in urban morphology and planning. Had articles and book chapters on physical development and planning history of Turkish cities as well as their morphological transformation. After being worked at the University of Mersin between 2006 and 2020, he has been a member of the Department of City and Regional Planning at Çukurova University, Adana, Turkey. 